\title{
Some College Library Investigations at Columbia University
}

Until her retirement in 1942 Miss Fay was associate professor of library service at Columbia University. The series of studies she describes in this article are further illustrated in the present number by the condensed versions of essays by Maurice H. Smith and Rea J. Steele.

$\mathrm{I}^{\mathrm{N}}$ PLANNING INVESTIGATIONS in the college library field when the master of science curriculum was begun in the School of Library Service in 1928, consideration was given to the various aspects of college libraries that needed study, to subjects that could be encompassed by students in their year of graduate study, and to subjects that would offer different types of research techniques for the students' training and experience.

Some sixty or more studies were made in the fields of organization and administration, budgets, staff activities, student assistants, history of libraries, book collections in relation to the teaching program of the college, periodical holdings in various subject fields in relation to the curriculum, the book-reviewing adequacy of subject journals for book selection in college libraries, library reports as source material, students' reading and reading interests, and so forth.

\section{Book Collections in Relation to Curricula}

It may be of interest to college librarians to know the results of two series of these investigations, both series being con- cerned with distinct aspects of book selection. The first series of nineteen essays comprised studies of the adequacy of book collections, as they existed, in relation to the educational programs of the colleges and covered the subjects of: science in general, zoology, American history, English history, fine arts, anthropology, economics, religion, Spanish, philosophy, French literature of the seventeenth century, general books in the literature of agriculture, social sciences in general, and sociology. The types of libraries covered were state teachers colleges in Nebraska, New York, Texas, and West Virginia; liberal arts colleges; junior colleges; landgrant colleges; Catholic colleges; and one foreign institution, the University of Oslo. ${ }^{1}$

The results of this series of essays as a whole have shown that book selection has been far from systematically done in every type of college library; that the selection process has shown limited cooperation of faculty and library staff; that the objectives of supplying printed materials for the furtherance of the educational program of the college have not been attained; and that selection routines and methods have been unsatisfactory if not altogether nonexistent.

Further investigation into the conditions, methods, and tools of book selec-

1 A condensation of an essay belonging to this series, by Maurice $H$. Smith, appears on pages 2 I $7-27$ of the present number of College and Research $L i$. braries. 
tion has been made in one particular study of the state teachers colleges of New York and in the series on book reviewing in subject journals described and summarized in this article.

\section{Adequacy of Book Reviewing in Subject Journals}

The series of nineteen essays described above, together with the results of two discussions outside the School of Library Service, led to studies on the adequacy of book reviewing in subject journals for college library book selection. One of the discussions was the recurrent criticism in the College and Reference Section of the A.L.A. of the lack of any satisfactory book selection aids, in the field of current titles, for college libraries; the expressed opinion that the Booklist did not suffice; and the agitation for a special current list for college libraries. This matter was discussed at several annual meetings; resolutions were passed; A.L.A. Headquarters took the idea under advisement; and the A.C.R.L. appointed a committee to find out, by the investigation of book reviewing in professional and subject journals, whether a new aid was really needed and, if so, to suggest the kind of list college librarians would find satisfactory.

The other discussion, outside the library field, was of even greater significance in determining the need of investigating book reviewing in subject journals. The American Historical Association's Committee on Planning Research published a report in 1932 entitled, "Historical Scholarship in America: Needs and Opportunities." This committee offered some questions to be answered by groups of specialists in ancient history, medieval history, modern European history, and
American history. Two of the questions were:

1. Are there any obvious shortcomings in our professional journals that might be corrected? Are our standards of book reviewing adequate?

2. Have we at the present time adequate facilities for keeping posted on recent publications, both periodical and in book form?

The various specialists expressed their opinions, and the committee summarized their answers:

A general criticism made of historical journals concerns the reviewing and bibliographical service. Too of ten reviews do not review the book. They dilate upon insignificant errors and thus give a misleading impression of the work under consideration. There is a general demand for more critical appraisal both of the scientific and literary merits of books. Without reducing the number of reviews, more emphasis and space should be given to important works. We suggest that the editors take steps to procure funds for the purchase of significant works which they cannot otherwise secure for review. We recommend that sessions at the meeting of the American Historical Association be occasionally devoted to the consideration of the art of book reviewing. (Report, p. 39-40)

With these three instigators-our own findings from the first series of nineteen studies, the college librarians' criticism of the lack of selection aids for college libraries, and the historians' indictment of their journals in regard to book reviewing-the second series of studies, concerned with another aspect of book selection, had impelling reasons for being undertaken. Furthermore, following the American Historical Association's report of 1932, there appeared in the American Journal of Psychology (v. 46, p. 508-1 1, July 1934) an account of a study of book reviews in psychological periodicals by 
Richard S. Schultz and Helen Pallister. Their investigation of nine journals, Journal of Abnormal and Social Psychology, American Journal of Psychology, Journal of Applied Psychology, Psychological Bulletin, Psychological Clinic, Psychoanalytic Review, Journal of Social Psychology, Journal of General Psychology, and Pedagogical Seminary, for the year 1933 resulted in the following six conclusions :

This study shows in general that available facilities for book reviews are not being used to the fullest extent. A number of obvious defects appear in the present system of book reviewing. These are briefly as follows:

I. A small number of pages are given to book reviews in all but two journals: 5 I.6 per cent of the space utilized for book reviews is confined to the American Journal of Psychology and the Psychological Bulletin.

2. Most of the journals review few books. The American Journal of Psychology reviewed the largest number of books in 1933, amounting to 43.6 per cent of the total.

3. There is considerable delay in publication of reviews. Only 8.2 per cent of the books published in the English language are reviewed during the year of publication and 46.6 of the reviews do not appear until two years after publication.

4. Of the books reviewed 85.8 per cent were reviewed but once.

5. There are not many assiduous reviewers: 60.9 per cent of them were credited with only one book.

6. There is a question as to the professional competency of the reviewers. Only 42.2 per cent of the books were reviewed by full members of the American Psychological Association and over 15 per cent by nonmembers.

Value of Book Reviews in Subject Journals for College Library Book Selection

From 1937 to 1942 eleven studies in the second series at the School of Library Service were completed, covering the subjects of chemistry, political science, modern language philology, ancient classics, engineering, foods and nutrition, biology, higher education, music, English and American literature, and economics. Other investigations, covering periodicals in history, philosophy, sociology, and general American Catholic periodicals, are in course of development, the one in philosophy now being nearly finished.

In general, the purpose of these investigations has been twofold: I. To test the assumption of the American Historical Association committee that periodicals in the history field were not adequate in their reviewing features, by (a) extending investigations to cover many other subjects, (b) developing as objective methods as possible for such testing, and (c) evaluating the reviews for the particular purpose of book selection in college libraries; and 2. to make the cvidence obtained available to college librarians.

This article endeavors to present a summary of the results of these studies. For full information, the librarian should consult the complete essays, which may be borrowed from Columbia University Library on interlibrary loan.

The selection of journals to investigate was the first step taken in all cases. That involved finding out which had regular book-reviewing sections, determining the limitation or nonlimitation to journals published in the U.S.A., ascertaining which journals were probably in most college libraries (by checking the Union List of Serials), and learning which journals were deemed best by specialists. The last was accomplished by checking such periodical lists as the Hilton list, used by the North Central Association for ac- 
crediting purposes; the list of periodicals in the Shaw List of Books for College Libraries; and the Lyle and Trumper Classified List of Periodicals for College Libraries - all being selected lists based on the pooled opinions of college faculties and library staffs. For some studies such information was obtained by writing directly to various faculty specialists and librarians for opinions.

\section{Basis of Evaluation}

Before determining criteria for a basis of the evaluation of reviews, the literature on book reviewing was read and all elements considered essential to a satisfactory book review were listed. It is interesting to note that, of practically all sources consulted, Miss Haines' Living with Books covered all the elements of adequacy most satisfactorily. The consequence was that, in the main, criteria of evaluation in all these studies were based on Haines. The study of education journals used in addition the criteria noted in Maxwell's "Use of Score Cards in Evaluating Textbooks."

The number of criteria were generally ten: six for the factual content of the review-author, imprint, form, purpose, subject, physical characteristics-and four for the critical content-reliability, presentation, value, and comparison. The next step was preparing a rating scale to be used on the criteria. In all but two studies a six-point scale was used; in one, a five-point scale; and in the investigation of education journals, a score card, which developed a more refined measurement than did the rating scales.

For finding out other important facts, additional techniques were used. One of these facts was the determination of the time-lag between the date a book was published and the appearance of a review of it. This was one of the time-consuming and really arduous steps in the studies, due to the fact that, if the evidence was to have any significance, it must show timelag by months at least. In the case of books printed in the U.S.A. it meant checking every title with the copyright catalog in order to obtain the month of publication. Sometimes the Publishers' Weekly had to be checked for noncopyrighted material. For titles of English origin the English Catalogue and Whitaker's Cumulative Booklist were checked; for the books published in other countries, corresponding national bibliographies were checked.

An additional type of verifying was that required to establish the authority of the reviewer. In many instances neither biographical dictionaries, college catalogs, nor directories of professional societies would yield information. In the political science study it was necessary to get permission to consult and then go to the American Political Science Association's headquarters to check the card file of members of that organization.

\section{Policies of Journals}

One particularly interesting sort of information gathered in several of these studies had to do with the editorial policies of the journals under consideration. To get this required the sending of a letter, with a small number of questions arranged for easy answering, to each editor. Such questions as: Who selects the reviewer? What is the basis of selection (subject specialists not connected with the journal, members of the editorial staff, members of the university faculty)? Are voluntary reviews accepted? Is a time limit placed on the reception of the review for publication or is the review pub- 
lished regardless of the time-lag? Is the reviewer given a space limitation? If so, approximately what space? What books are selected for reviewing? Has the journal a standard form for the bibliographical entry?

In the study of educational journals the score card developed by the investigator was sent for criticism to Miss Haines, Douglas Waples, W. W. Charters, C. V. Good, Carter Alexander, Louis S. Shores, Ethel M. Feagley, and Marion Emsley Hawes, and revised in the light of their comments. In some studies librarians also were asked to state to what extent the particular journals were used by them and by the members of their faculties for obtaining information about books for selection for the college library.

\section{Summary}

The titles in these two series of masters' essays are listed at the end of this article. Here is given a summary of the eleven finished studies and of the one nearly completed essay in that series which has to do with the book-reviewing adequacy of subject journals for book selection in college libraries:

\section{Chemistry: (Bentley)}

Journals investigated. Years 1930 and 1935. 513 reviews.

Journal of the American Chemical Society Journal of Physical Chemistry

Journal of Chemical Education

Transactions of the Faraday Society

Conclusions reached:

I. Representation of the publications of all countries and particularly of the U.S.A., England, France, and Germany is satisfactory.

2. Journals are weak in promptness of review, ordinarily waiting three or four months after publication, or longer, before reviewing.

JUNE, 1944
3. In critical and evaluative qualities the reviews are inadequate. Stronger in descriptive than in critical presentations. The librarian needs, particularly, more definite statements about accuracy, greater comparison with similar books, and considerably more information on the textual and physical qualities of the books and on the author's qualifications and the basis of his work.

\section{Political Science: (Henry)}

Journals investigated. Year 1935. 1294 reviews. Periodicals in the subject field.

American Political Science Review

Annals of the American Academy of Political and Social Science

Political Science Quarterly

Journal of Political Economy

General book-reviewing media:

Books (Herald-Tribune)

Nation

New Republic

New York Times Book Review

Saturday Review of Literature

Survey Graphic

Conclusions reached:

I. Only a small percentage of books reviewed represented foreign literature. Publications were largely confined to those of English-speaking countries.

2. Number of reviews was high. Professional journals slower in reviewing than were the nonprofessional ones.

3. Reviewing situation in political science periodicals is not satisfactory.

4. Authority of reviewer shows a high percentage in professional journals, and $3 \mathrm{I}$ per cent of nonprofessional periodical reviewers were members of a political science organization.

Modern Language Philology: (Boyce)

Journals investigated. Years 1937 and 1938. 784 reviews.

Journal of English and Germanic Philology

Modern Language Journal

Modern Language Notes

Modern Philology

Philological Quarterly 
Conclusions reached:

I. In critical evaluation the reviews adequately meet the requirement for critical appraisal with three important exceptions: (I) no information about the author of the work; (2) little comparison with other similar works; (3) few facts about textual or physical make-up.

2. Median time-lag of eleven months between appearance of the works and the reviews, with range from one month to ten years, renders journals inadequate for current book selection. Two of the journals very inadequate in international range of reviewing.

3. Selection of reviewers is nonbiased; selection of books for review is limited to those sent by publishers and authors.

4. Lack of reviews of American and contemporary works indicates neglect in reviewing policy.

5. Pronounced prevalence of favorable reviews in all journals.

6. In the last analysis the reviews fulfill certain specific requirements of book selection but fail to meet total requirements to a sufficient degree to appraise them as adequate for book selection for college libraries.

\section{Ancient Classics: (McAtee)}

Journals investigated. Year 1937. 485 reviews.

American Journal of Philology

Classical Philology

Classical Review

Classical Weekly

\section{Conclusions reached:}

I. Reviews are eminently satisfactory in their treatment of form, subject and scope, purpose and extent; only slightly less adequate as regards comparison and author's basis of work and accuracy. Fairly good with respect to description of textual and physical characteristics and passable concerning comments on structure and expression. They are disappointing with regard to statement of qualifications of the author.

2. The time interval between publication of book and appearance of review is too great to allow the reviews to be of all the aid they might be to college library book selection.

3. Very comprehensive in their inclusion of reviews of foreign publications. Language difficulties seem to form no impediment when there is question of reviewing a book which an editor judges will be of interest to the readers of his journal.

4. Proportion of unfavorable to favorable reviews is approximately $1-3$. If these findings are representative, the classics reviewers can scarcely be considered excessively lenient.

5. Amount of duplication of reviews in the different journals is considerable, but more nearly simultaneous appearance of the reviews of the same books is desirable.

\section{Engineering: (Whitford)}

Journals investigated. Year 1936. 437 reviews.

Engineering (British)

Engineering News-Record (Civil engineering)

Mechanical Engineering (Mechanical engineering)

Electrical $W$ orld (Electrical engineering)

Chemical and Metallurgical Engineering

Power Plant Engineering

Conclusions reached:

r. Information of a factual or descriptive character is usually given in these reviews, but critical or evaluative comment to the extent requisite in book selection is not given.

2. Greater promptness of reviews is evidenced in engineering journals than in chemistry or psychology. Space limitations seem to be the determining factor which causes a considerable portion of reviews to be spread over the course of a year after publication.

\section{Foods and Nutrition: (Cullipher)}

Journals investigated. Years 1935, 1936, and 1937. Ior reviews.

Journal of the American Dietetics Association

Journal of Home Economics

Nutrition Abstracts and Reviews

Journal of the American Medical Association 
American Journal of Digestive Diseases

Quarterly Review of Biology

Conclusions reached:

1. These journals make an effort to secure and review outstanding books in the field.

2. Too few of the reviews are signed. Those that are, are written by specialists.

3. Books are reviewed with enough frequency for a book selector to get the opinion of more than one reviewer on many books.

4. Shortest interval between publication and review is two months.

\section{Biology: (Doggett)}

Journals investigated. Years, 1935-38. 769 reviews.

American Microscopical Society. Transactions

Ecology

Quarterly Review of Biology

Phytopathology

Yale Journal of Biology and Medicine

Conclusions reached: This study, which has attempted to evaluate the objective and subjective aspects of the reviews, finds some strong and some weak points.

I. Editors feel responsible for the assignment of the books to be reviewed.

2. Responsibility for the statements in the reviews may be found, as they are signed except in the Quarterly Review of Biology.

3. Reviewers are mostly specialists.

4. Analysis of contents of the reviews revealed meagre information about authorship, basis for subject matter of the book, and its purpose.

5. Ecology and Phytopathology had lengthy reviews; Quarterly Review of Biology had many but short reviews.

\section{Higher Education: (Steele) ${ }^{2}$}

Journals investigated. Year 1938. $285^{\circ}$ reviews.

Association of American University Professors. Bulletin

2 For an abbreviated form of Miss Steele's essay see pages 228.37 of this issue of College and Research Libraries.
Harvard Educational Review

Journal of Educational Research

Journal of Higher Education

Junior College Education

Conclusions reached: Reviews in the field of higher education furnish the librarian with sufficient bibliographical information and describe contents of books reviewed quite fully but leave much to be desired in evaluating the books for selection purposes. Of books reviewed only io per cent were reviewed more than once. Sixty-seven to 84 per cent of all signed reviews attempted to give an impartial estimate of the book by agreeing or disagreeing with the author's point of view; Io to 29 per cent only of the same reviewers stated whether or not the book had the quality necessary to make it a permanent contribution. Another weak spot was in the field of comparison. Only 20 to 22 per cent of reviews compared a new book with other better-known titles. Score card evaluation reveals:

I. On the whole journals review recent material.

2. Full authority of reviewer is seldom given. In most instances only name of the person and institution with which connected were mentioned.

3. One of the weakest spots in manner and treatment of reviews was in lack of comparison with other titles.

4. Scope and form of book reviewed usually well-covered.

5. Reviews did not rate very high on information about author of books. Few reviewers mentioned author at all or when they did gave no information about him.

6. Reviews did not reveal to any great extent the originality or permanent value of the book.

7. Physical features, such as adequate index, documentation, appendices, and bibliographies, received little attention.

8. Trade information adequately given.

9. Usually the longer the review the higher it rated on the score card, although average rating for an individual review was only twenty-three out of a possible score of forty-one. The length varied, with all but two of the journals averaging over five hundred words for a single review. 


\section{Music: (Hawkins)}

Journals investigated. Years 1935 and 1938. 312 reviews.

Etude

Music Educators Journal

Modern Music

Music and Letters

Saturday Review of Literature

Conclusions reached:

I. Subject and scope of book: sufficient information usually given.

2. Evaluative comment: not satisfactory.

3. Comparison with other books: almost entirely lacking.

4. Bibliographical information, including physical characteristics: needs more attention.

5. Primary details of author, title, and date: are with few exceptions given accurately.

6. Qualifications of both author and reviewer: might be considered more thoroughly with profit.

7. Fairly prompt reviewing, in comparison with other fields: 50 per cent of the titles reviewed within eight months; 22 per cent a year or more after publication.

\section{English and American Literature:} (Rogan)

Journals investigated. Year 1938. 174 reviews.

\section{American Literature \\ Englische Studien \\ Etudes Anglaises \\ Review of English Studies}

Conclusions reached:

1. Time-lag between publication of book and the review is none to thirty-nine months. Greatest number of reviews fall within the range of ten to twelve months.

2. From the standpoint of critical evaluation the reviews are not entirely adequate.

3. Very few books other than English and American are reviewed.

4. 42.48 per cent of the books published (as listed in the Annual Bibliography of English Literature, American Bibliography in P.M.L.A., etc.) are not reviewed in these journals.
5. 50.79 per cent of the reviewers that were identified are members of university faculties.

6. Viewpoints of reviewers are: average rating, predominately favorable, 33.37 per cent; extremely favorable, 30.68 per cent; predominately unfavorable, I6.4 per cent; extremely unfavorable, II.I per cent; neutral, 8.46 per cent. It is apparent that favorable viewpoint is unduly stressed.

Economics : (Rogers)

Journals investigated. Years 1936 and 1938. II 88 reviews.

American Economic Review

Journal of Political Economy

Quarterly Journal of Economics

Economic Journal

Economics

Conclusions reached:

I. The book reviews give little information on several points important to the librarian:

a) The soundness and value of the economic thesis of the book.

b) Whether or not the book can safely be predicted to be a contribution of one kind or another to economic literature.

c) The possible uses of the book and by whom.

d) The background of the author and his authoritativeness.

e) The authoritativeness of the reviewer.

2. Most of the reviews appear within the year following the publication of the book reviewed. There is little opportunity of comparing reviews of titles, however, because most reviews are in only one journal, there is rather small duplication of reviews on same titles, and the journal ranking second in number of reviews included lags far behind in promptness of the reviews' appearance.

3. Neither of the two American journals studied which were indexed in the one review index examined made a good showing in the number of their reviews indexed.

4. Instructions are not given to the reviewers as a part of editorial policy except in minor instances, but an attempt is made by the journals to secure competent re- 
viewers and to review only worth-while books.

5. Possibly a better and more objective way to check on the real adequacy of the reviews would be to pool the findings of a group of experts with a knowledge of economics, college curriculum needs, and college librarians' book selection needs, who have compared actual books with reviews.

6. Possibly needed improvements in reviewing could be attained if the needs of those concerned with book selection for the libraries of our colleges could be placed before the editorial boards of the reviewing journals.

\section{Philosophy: (Maxfield)}

Journals investigated. Year 1938. 564 reviews.

Ethics

Hibbert Journal

Journal of Philosophy

Mind

Philosophical Review

Conclusions reached (tentative, since work is still in progress):

I. Three journals, viz., Ethics, Journal of Philosophy, and Philosophical Review, are far ahead of the others as regards the number of satisfactory reviews; the diffculty with Hibbert Journal and Mind be- ing partly the fewness of their reviews of any kind.

2. In spite of the many reviews it runs, Philosophical Review is inferior to Ethics and Journal of Philosophy, especially because its reviews are slow in appearing.

3. In all journals except Philosophical Review the majority of reviews are adequate, although not so by a large margin.

4. As a group, the reviews examined are stronger in description than in criticism, this being particularly true in Philosophical Review.

5. Slightly more than one half of all the reviews appeared within a year of the publication of the books and a little over one half of these could be judged as adequate.

6. Only in Journal of Philosophy and Philosophical Review was there any considerable representation of books not originating in England or America.

7. 84 per cent of the titles treated were reviewed only once.

8. Most of the reviewers were authorities, although minor specialists rather than major authorities stand out among the authors of adequate reviews.

9. The reviews rated as satisfactory tended to be favorable to the books dealt with; others were neither predominately favorable nor unfavorable.

10. Fairly successful book selection could be done from the journals studied.

\section{List of Studies of Book Collections in Relation to Curricula}

Baker, Frances N. "The Science Books in the Normal School Libraries in New York State." 1937.

Boughter, Vivian R. "Are the Book Resources in American History in the West Virginia Teachers Colleges Adequate?" 1936.

Collier, Amelia. "The Book Collection in English History for a College Library." 1930.

Dunn, Sister Helen. "A Minimum Basic List of Spanish Books for the Four-Year Liberal Arts College." 1940.

Falvey, Father. "A Survey of the Holdings in Philosophy of Representative
Catholic College Libraries, with an Authoritative List of Books in the Field." 1940.

Foster, Anna E. "Building a Book Collection in the Seventeenth Century for a College Library." 1930.

Hausdorfer, Walter. "The Problem of Selecting Books and Periodicals in Zoology." 1930.

Jenssen, Hans. "Building the Book Collection of the Institute of Economics at the University of Oslo." 1937.

Lancaster, Lucy Lee. "Do the Libraries of Land-Grant Colleges Provide a Representative Collection of Books for Back- 
ground Reading in Agricultural Literature?" I93I.

Littlefield, Lucile J. "A Fine Arts Collection for a Library of a Teachers College." 1938.

McLaughlin, Madge. "The Selection of Anthropology Books for the Undergraduate Liberal Arts College." I 937.

Moll, Father Boniface E. "A Basic List of Books in Sociology for Catholic Liberal Arts Colleges." I 939.

Russell, Abi. "A Fine Arts Collection for a Liberal Arts College Library." I93I.

Silvers, Josephine L. "A Study of the Science Collections in the State Teachers Colleges of Nebraska." I938.
Sister Mary Genevieve. "Book List for a Proposed Curriculum in Religion for Women's Catholic Undergraduate Colleges." I 934.

Stone, Ermine. "A Book Collection in the 300's for a Junior College Library." I 929.

Tashjian, Nouvart. "A Book Collection in Economics for an Undergraduate College Library." 1930.

Thompson, M. Florence. "A Book Collection in American History for a Junior College Library in California." I930.

Wyatt, Mildred. "A Study of the Science Collections in the Teachers College Libraries in Texas." 1936.

\section{List of Studies of the Book-Reviewing Adequacy of Subject Journals}

Bentley, Phyllis D. "The Book-Reviewing Adequacy of Certain Professional Chemical Journals for Book Selection in the College Library." 1937.

Boyce, Margaret. "The Book Reviewing Adequacy of Certain Literary Journals for College Library Book Selection." I939.

Cullipher, Martha R. "The Book Reviewing Adequacy for College Library Book Selection of Certain Technical Periodicals Relating to Foods and Nutrition." 1939.

Doggett, Marguerite V. "The Extent to Which Book Reviews in Certain Biological Journals Meet the Need of College Library Book Selection." I 940.

Hawkins, Jane S. "The Book Reviewing Adequacy of Certain Musical Journals for College Library Book Selection." I94I.

Henry, Eugenia M. "The Book Reviewing Service of Some American Journals of Political Science." I 939.

McAtee, Sister Jane Frances. "The Book
Reviewing Adequacy of Certain of the Classical Periodicals for College Library Book Selection." I939.

Maxfield, David. "The Book Reviewing Adequacy of Certain Journals in the Field of Philosophy from the Point of View of College Library Book Selection." (Title tentative, as work is still in progress.)

Rogan, Mme. Marie Joseph. "Value of Book Reviews of English and American Literature for College Library Book Selection." I94I.

Rogers, Mary E. "The Book-Reviewing Adequacy of Certain Economic Periodicals for Use in College Library Book Selection." 1942.

Steele, Rea J. "The Book Reviewing Adequacy of Certain Periodicals in the Field of Higher Education for College Library Book Selection." 1940.

Whitford, Robert H. "Evaluation of Certain Technical Book Reviewing Media as Book Selection Aids in a College Technology Library." 1939. 